\title{
Switching-Costs, Corporate Image, Product Quality, and Satisfaction Level effect on Customer Loyalty: E- Commerce Shopee
}

\author{
Nina Valentika ${ }^{1}$, Vivi Iswanti Nursyirwan², Sasmita Sari Ardaninggar ${ }^{3}$ \\ 1,2,3Pamulang University, Pamulang, Indonesia \\ \{dosen02339@unpam.ac.id ${ }^{1}$, dosen02226@unpam.ac.id², dosen01532@unpam.ac.id $\mathrm{d}^{3}$ \}
}

\begin{abstract}
This research has discussed the relationship between switching-costs, company image, product quality, customer satisfaction, and loyalty. This research has modified the research of Xhema J et.al (2018), namely by adding satisfaction variables and using Structural Equation Model-Partial Least Square. Also, this research uses a case study e-commerce shopee. This research has found a relationship between product quality and satisfaction with loyalty with a real level of $10 \%$.
\end{abstract}

Keywords: E-Commerce, SEM-PLS

\section{Introduction}

Shopping through E-Commerce or online stores increased during the Covid-19 Pandemic. Business transactions via electronic internet cable are called e-commerce [1]. Loyalty is one factor to increase profits in E-Commerce. Loyalty commitment to buy or support products and services that are preferred in the future are held in depth despite the influence of the situation and potential marketing efforts for customers to switch. Many factors encourage customers to be loyal: customer satisfaction, trust, dedication, corporate image, communication, and switching cost [2],[3]. Costs faced by buyers when switching from one company to another are called switching costs. These costs can be monetary or non-monetary. The literature states that the higher the switching costs the stronger the level of loyalty. Another important factor in online shopping is satisfaction. Satisfaction arises from happiness and frustration after comparing people's expectations and product performance. This can be also called customer experience [4]. Relationship between company and customer and makes the customer vulnerable to competitive offers is influenced by the quality of products or services and their variability [5]. Having customers who plan to return to the future in the same company is one of the main goals of a company. This goal can be achieved by meeting customer expectations with quality products [6]. Corporate image is the general impression of the company in the public's mind [7]. The perception that customers create for a particular company (through word-of-mouth) influences future buying intentions [8]. Familiar assessments have a greater impact on a person's quick reactions [9], so if someone close to us says something positive for a company, it affects our behavior [10]. Many studies have examined customer loyalty. One of the studies is Xhema $\mathrm{J}$ et al. [11]. The main of research objective is to understand the impact of cost switching, product quality, and company image on customer loyalty in the Kosovo retail market. It used correlation coefficient and regression. Based on Xhema $J$ et.al research [11], there is a positive relationship between switching costs, corporate image, product quality, and customer loyalty This study is 
a modification of Xhema $\mathrm{J}$ et.al research [11], namely by adding the effect of satisfaction on loyalty and using the Structural Equation Model-Partial Least Square.

\section{Literature Review}

\subsection{Customer Loyalty}

There is not generally accepted definition of customer loyalty, but it is understood as a commitment to attitude or behaviour towards a brand [12]. Being a loyal customer recommends the company to others, says positive yourself a future customer of a certain company [13]. When a customer has a positive attitude toward the company, he will buy back the company's products and recommend them to others [14].

Many factors encourage customers to be loyal: customer satisfaction, trust, dedication, corporate image, communication, and switching cost [2],[15]. The company's profitability factor is affected by customer loyalty and repurchase decisions. There are many factors such as product quality, satisfaction or trust that affect customer intention to repurchase. The customer's intention to repurchase is influenced by economic factors associated with the purchase of the product [16]. There are five indicators of loyalty, namely, repeat purchase product, repeat it with more quality, purchase other products, prioritize the company, and recommend to others [17].

\subsection{Switching Cost}

Costs faced by buyers when switching from one company to another are called switching costs. These costs can be monetary or non-monetary. The literature states that the higher the switching costs the stronger the level of loyalty. This happens because sometimes loyal customers only make repeat purchases (only behavior) and they do this because costs for switching the company are high [18]. There are four indicators of switching costs, namely, cost incurred by lower quality potency, cost incurred by quality inconsistency potency, New and additional cost, and Negative image risk [17].

\subsection{Corporate Image}

Corporate image is the general impression of the company in the public's mind [7]. The perception that customers create for a particular company (through word-of-mouth) influences future buying intentions [8]. Familiar assessments have a greater impact on a person's quick reactions [9], so if someone close to us says something positive for a company, it affects our behavior [10]. Corporate image is divided into five namely store layout, store prestige, service quality of store, products, in-store promotion, support services and equipment [19]. The distance between the product space between one product and another presented to the customer is called the store layout [19]. The store's reputation that occurs as a result of long- term involvement between the company and consumers in the long term is called store prestige [19]. The whole product of service provided to create the satisfaction needed by consumers for what they buy is called quality prestige. The object of a thing that is marketed through advertising and aims in marketing activities is called a product [19]. Investments made to promote their products in stores, such as shelf positions, special screens, promotional brochures, etc are called In-Store Promotion. Tools such as shopping carts, and the product return process provided by stores to consumers are called support services and equipment[19]. 


\subsection{Product Quality}

Relationship between company and customer and makes the customer vulnerable to competitive offers is influenced by the quality of products or services and their variability [5]. Having customers who plan to return to the future in the same company is one of the main goals of a company. This goal can be achieved by meeting customer expectations with quality products [6]. If customer expectations are met or exceeded, we can have loyal customers [20]. There are three indicators of product quality, namely, meet customer needs, good quality products, and consistent good quality [17].

\subsection{Satisfaction Level}

One of the most important factors in online shopping is satisfaction. Satisfaction arises from happiness and frustration after comparing people's expectations and product performance. This can be also called customer experience [4]. Yeh and Yung-Ming [21], Nuryakin and Naili [22] agreed that the level of satisfaction comes from evaluating the results of employees' work in providing a service to a customer. The quality of products and services is given by the satisfaction level [23].

Customer Satisfaction is divided into two, namely customer feeling and expected performance [24]. Customer feeling is the experience felt by consumers of the decision to choose a product that affects the response to the image of a brand that ultimately has a close relationship with customer satisfaction [24]. Expected performance is a service that is felt by consumers for what is provided by the company that affects customer satisfaction if the services provided are in line with what is expected [24].

\subsection{Hypothesis}

The hypotheses in this study are as follows:

H1 : Switching-Costs will have a significant effect on Customer Loyalty

H2 : Corporate Image will have a significant effect on Customer Loyalty

H3 : Product Quality will have a significant effect on Customer Loyalty

H4 : Satisfaction level will have a significant effect on Customer Loyalty

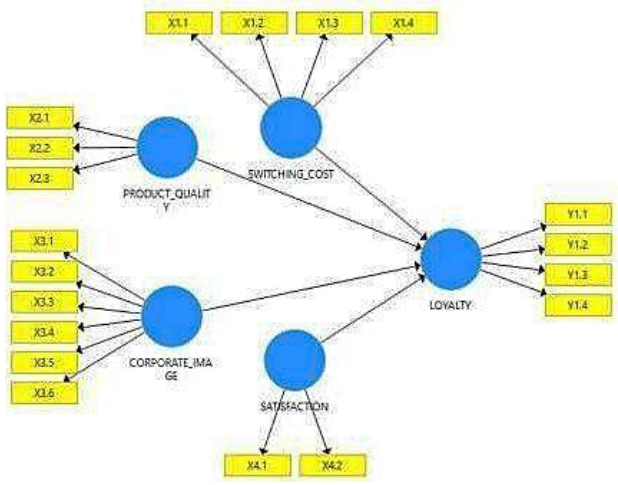

Fig. 1. Conceptual Model for Proposed Framework 


\section{Data and Research Technique Analysis}

The research population is e-commerce shopee consumers. The simple random sampling method is used for sampling in this study. The sample criteria in this study are consumers who have shopped at least once and are students of the Mathematics Study Program, Faculty of Mathematics and Natural Sciences, Pamulang University. The reason the sample was chosen was that the researcher worked at Pamulang University as a lecturer. The number of samples was determined using the Slovin formula at a $10 \%$ significance level. The calculations are as follows:

$$
\begin{aligned}
n & =\frac{N}{1+N(k)^{2}} \\
& =\frac{90.7 \times 10^{2}}{1+90.7 \times 10^{6}(10 \%)^{2}}
\end{aligned}
$$

Where :

$\mathrm{n} \quad$ : number of samples

$\mathrm{N}$ : the total population; 90.7 million Shopee consumers in Indonesia

$\mathrm{k}$ : the error rate used which is $10 \%$

\subsection{Measures}

All items on the questionnaire were measured using a 5-point Likert scale, ranging from "strongly disagree" to "strongly agree". There are five parts to the questionnaire, namely (1) Switching-Cost, (2) Corporate Image, (3) Product Quality, (4) Customer Loyalty, and (5) Satisfaction. Data was collected through a questionnaire which was then distributed online (google form) to respondents. The indicators in this study were drawn from several previous studies. loyalty, product quality, and switching cost scales, developed by Susanti et.al [17]. Meanwhile, Corporate image was developed by Ene and Özkaya [19]. Customer Satisfaction was developed by Huang, Yen, Liu, and Chang [24].

\section{Results and Discussion}

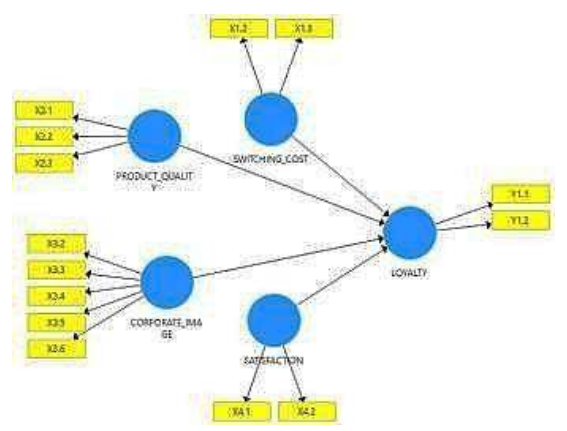

Fig. 2. Final Research Model 
The construct can be said to be valid and reliable if the Average Variance Extracted (AVE) value is greater than 0.5 and the composite reliability $(\mathrm{CR})$ is greater than 0.7 .

\subsection{Outer Model}

Table 1. AVE and CR

\begin{tabular}{ccc}
\hline Variable & $\begin{array}{c}\text { Average Variance Extracted } \\
\text { (AVE) }\end{array}$ & Composite realibility (CR) \\
\hline Switching Cost & 0.820 & 0.901 \\
Product Quality & 0.818 & 0.931 \\
Corporate Image & 0.701 & 0.921 \\
Satisfaction Level & 0.855 & 0.922 \\
Loyalty & 0.833 & 0.909 \\
\hline
\end{tabular}

Loading and cross-loading tests are applied in this research to confirm the validity and reliability test. Based on Loading and Cross-loading tests, it is found that all variables are valid and reliable.

Table 2. Cross Loading Model

\begin{tabular}{lccccc}
\hline & Switching Cost & Product Quality & Corporate Image & Satisfaction & Loyalty \\
\hline X1.2 & 0.877 & 0.452 & 0.423 & 0.472 & 0.331 \\
X1.3 & 0.934 & 0.418 & 0.411 & 0.569 & 0.445 \\
X2.1 & 0.447 & 0.910 & 0.502 & 0.585 & 0.536 \\
X2.2 & 0.426 & 0.916 & 0.577 & 0.594 & 0.606 \\
X2.3 & 0.419 & 0.887 & 0.601 & 0.629 & 0.597 \\
X3.2 & 0.377 & 0.595 & 0.872 & 0.656 & 0.603 \\
X3.3 & 0.455 & 0.620 & 0.878 & 0.730 & 0.647 \\
X3.4 & 0.422 & 0.563 & 0.876 & 0.691 & 0.624 \\
X3.5 & 0.273 & 0.384 & 0.800 & 0.542 & 0.457 \\
X3.6 & 0.365 & 0.374 & 0.754 & 0.533 & 0.413 \\
X4.1 & 0.520 & 0.596 & 0.633 & 0.917 & 0.661 \\
X4.2 & 0.552 & 0.637 & 0.772 & 0.933 & 0.731 \\
Y1.1 & 0.391 & 0.638 & 0.698 & 0.736 & 0.930 \\
Y1.2 & 0.407 & 0.527 & 0.507 & 0.634 & 0.895 \\
\hline
\end{tabular}

Based on Table 3, we can see that all indicators are valid. This is because the loading factors are more than 0.7 against the intended constructs and their cross-loading which means this research has fulfilled convergent validity and discriminant validity.

\subsection{Inner Model (R-Squared and Significant Test)} 4.

Based on the SEM-PLS structural model test, the R-square in this study is presented in Table

Table 3. Cross Loading Model

\begin{tabular}{ccc}
\hline & R-Square & R-Square Adjusted \\
\hline Loyalty & 0.616 & 0.600 \\
\hline
\end{tabular}

The strength of the research model with the R-squared test is divided into 3 parts namely (a) 0.67-strong, (b) 0.33-moderate, and (c) 0.19-weak (Chin 1998). Table 4 shows that the strength of this research model is moderate. A significant test on the SEM-PLS model aims to analyze the effect of exogenous variables on endogenous variables. Also, hypothesis testing can be done 
using significance tests.

Table 4. Bootstrapping of Research Data- Significant Test

\begin{tabular}{cccc}
\hline & Original Sample & T-Statistics & P-Value \\
\hline Corporate Image $\rightarrow$ Loyalty & 0.166 & 1.181 & 0.238 \\
Product Quality $\rightarrow$ Loyalty & 0.224 & 2.396 & 0.017 \\
Satisfaction $\rightarrow$ Loyalty & 0.501 & 3.540 & 0.000 \\
Switching Cost $\rightarrow$ Loyalty & -0.037 & 0.497 & 0.620 \\
\hline
\end{tabular}

Based on Table 5, an explanation of the effects of the relationship of exogenous latent variables to endogenous latent variables is as follows:

a) The corporate image variable does not directly affect loyalty.

b) The product quality variable has a positive and significant effect on loyalty with a real level of $10 \%$. This indicates that the higher the quality of the products at shopee, the higher the loyalty of consumers.

c) Variable satisfaction has a positive and significant effect on loyalty with a real level of $10 \%$. This indicates that the higher the level of satisfaction, the higher the loyalty of consumers.

d) Variable switching costs do not directly affect loyalty.

\section{Conclusion}

The product quality variable has a positive and significant effect on loyalty with a real level of $10 \%$. Variable satisfaction has a positive and significant effect on loyalty with a real level of $10 \%$.

\section{References}

[1] Vermat, Shelly Cashman, Discovering Computers: Menjelajah Dunia Komputer Fundamental, Edisi 3, Jakarta: Salemba Infotek, 2007

[2] Bobâlcă.: Determinants of Customer Loyalty. A theoretical Approach. Journal of International Scientific Publications, 8 (2014)

[3] Doney, P. M. and Cannon, J.P.: An Examination of the Nature of Trust in Buyer-Seller Relationships. Journal of Marketing, 61(2) (1997)

[4] Chinomona, Richard., Godrey Masinge., Maxwell Sandada.: "The Influence of E-Service Quality on Customer Perceived Value, Customer Satisfaction and Loyalty in South Africa". Mediterranean Journal of Social Sciences. Vol 5 (9) (2014)

[5] Chandrashekaran, M., Rotte, K., Tax, S.S. and Grewal, R.: Satisfaction Strength and Customer Loyalty. Journal of Marketing Research, 44(1) (2007)

[6] Hellier, P. K, Geursen, G. M, Car, R. A. and Rickard, J. A.: Customer repurchase intention: A general structural equation model. European Journal of Marketing, 37(11) (2003)

[7] Agyei, P.M. and Kilika, J.M.: Relationship between Corporate Image and Customer Loyalty in the Mobile Telecommunication Market in Kenya. Management Studies, 2(5) (2014)

[8] Khan, B.: Factors Contributing to Customer Loyalty in Commercial Banking. International Journal of Accounting and Financial Reporting, 4(2) (2014)

[9] Andreassen, T.W.: The Effect of Corporate Image in the Formation of Customer Loyalty. Journal of Service Research, 1(1) (1998)

[10] Horaga, A. E., Ozora, O. and Stiefanie.: The Factors of Brand Image which Influence Customer 
Loyalty of J.Co. Business Administration (2012)

[11] Xhema $\mathbf{J}$ et al.: Switching-Costs, Corporate Image and Product Quality Effect on Customer Loyalty:Kosovo Retail Market. IFAC PapersOnLine. 51-30 (2018) 287-292

[12] Zhang, J. Q., Dixit, A. and Friedmann, R.: Customer Loyalty and Lifetime Value: an Empirical Investigation of Consumer Packaged Goods. Journal of Marketing Theory and Practice, 18(2) (2010)

[13] Abd-El-Salam, E. M., Shawky, A. Y. and El-Nahas, T.: The Impact of Corporate Image and Reputation on Service Quality, Customer Satisfaction and Customer Loyalty: Testing the Mediating Role. The Business \& Management Review, 3(2) (2013)

[14] Akbar, M. M.: Three Competing Models on Customer Loyalty in the Context of Mobile Subscribers. International Journal of Marketing Studies, 5(4) (2013)

[15] Doney, P. M. and Cannon, J.P.: An Examination of the Nature of Trust in Buyer-Seller Relationships. Journal of Marketing, 61(2). (1997)

[16] Valenzuela, L. M., Mulki, J. P. and Jaramillo, J. F.: Impact of Customer Orientation, Inducements and Ethics on Loyalty to the Firm: Customers' Perspective. Journal of Business Ethics, 93(2) (2010) 